\title{
Animal Models of Colorectal Cancer in Chemoprevention and Therapeutics Development
}

\author{
Shubhankar Suman, Albert J. Fornace Jr. and Kamal Datta* \\ Department of Biochemistry and Molecular \& Cellular Biology, \\ Lombardi Comprehensive Cancer Center, Georgetown University, Washington, DC, \\ USA
}

\section{Introduction}

Considering the complexity of genetic and epigenetic events that occurs during colorectal carcinogenesis and the uncertainty in relying solely on extrapolation from cell culture models, it is essential to use animal models relevant to the molecular characteristics of colorectal cancer (CRC). Requirements for a mouse model of CRC are that the model has relevance to the molecular pathways involved in human CRC, that there are correlates with factors that affect the frequency of the disease in human populations, and that the chemopreventive/therapeutic agent-induced signal is sufficient to carry out the project with an affordable and statistically significant number of mice. In this chapter we will discuss how animal models have not only advanced our understanding of CRC initiation and progression but have also greatly facilitated the development of newer chemopreventive and therapeutic strategies to reduce mortality and incidence.

\section{Animal models of colorectal cancer}

Use of animal models could significantly expedite not only the delineation of molecular pathogenesis of colorectal carcinogenesis but could also aid in the development of newer preventive and therapeutic strategies. Animal tumor models can be classified as spontaneous and artificially transplanted systems. Spontaneous tumor models are now being widely considered for studying the biology of carcinogenesis and development of chemopreventive or chemosuppressive drugs.

Initial animal models of CRC involved use of chemical carcinogens in mouse, rat, as well as in guinea pig. In the last two decades genetically modified mice such as APCMin/+ (Min: multiple intestinal neoplasia) with germline APC mutations at different sites have been extensively used for the investigation of therapeutic, chemopreventive and dietary factors for management of colorectal cancer (Hu et al., 2006; Gerner, 2007). Furthermore, studies to identify genetic modifiers of CRC are undertaken by generating mouse models representing molecular events involved in colorectal carcinogenesis like mismatch repair deficiency (MSH2-/-) and crossing

${ }^{*}$ Corresponding Author 
them with APCMin/+(Kwong \& Dove, 2009). Other models for CRC targeting relevant pathway are also being developed to elucidate chemopreventive and chemotherapeutic response to newer molecules (Kwong \& Dove, 2009). Because there is no ideal animal tumor model, which can mimic all the complexities associated with human CRC, the selection of an appropriate experimental model is crucial to study specific biologic end points towards the understanding of mechanistic, preventive and therapeutic aspects of the cancer.

\subsection{Rat models}

In the last few decades many murine models have been established that are useful for the investigation of initiation, expansion and progression of gastrointestinal (GI) cancers. In most of these models, Wnt signaling, mismatch repair, and TGF $\beta$ pathways are targeted not only to understand initiation and progression of CRC but also to evaluate various pharmaceutical and biological agents for prevention and treatment of CRC.

Normally CRC is not observed in rats $(<0.1 \%)$ (Goodman et al., 1980) except the WistarFurth/Osaka strain that spontaneously develops adenocarcinomas in 30-40\% of the animal (Miyamoto \& Takizawa, 1975). The rat models of colon cancer are developed using common carcinogens like AOM (azoxymethane), DMH (dimethylhydrazine), or PhIP (2-amino-1methyl-6-phenylimidazo [4,5-b]pyridine)(Corpet \& Pierre, 2003, 2005). Most of the carcinogen-treated rat models develop tumors in the colon and often progress to adenocarcinomas. However, long latency period of tumor development is a distinct disadvantage. Efforts have been made to generate target-selected mutations, including nonsense alleles by several laboratories resulting into development of a rat strain carrying a nonsense allele in codon 1137 of APC (Corpet \& Pierre, 2005). Interestingly, multiple intestinal neoplasms mostly in the colon were observed in F344 rats, commonly known as PIRC (polyposis in the rat colon) model, heterozygous for this allele and these animals survive for about one year (Zan et al., 2003; Smits et al., 2006; Amos-Landgraf et al., 2007). The rat models due to their size allows investigators to perform procedures like endoscopy, microCT (Computerized Tomography), and microPET (Positron Emission Tomography) imaging to evaluate chemoprevention or therapeutic interventions without sacrificing the animal.

\subsubsection{Rat models in chemoprevention and therapeutics development}

Although, dimethylhydrazine and its metabolites azoxymethane (AOM) and methylazoxymethanol are commonly used in the induction of colonic tumors in rat models, other carcinogens, like nitrosomethyl urea (MNU), specific nitrosamines and heterocyclic amines are also in frequent use. Many potential chemopreventive agents of colorectal cancer have been assessed in rat models. The effects of chemopreventive and therapeutic agents on initiation and progression of carcinogen-induced colonic tumors can be studied by varying the time of intervention. In rat models over 160 compounds have been screened for chemopreventive properties (Corpet et al., 2008) and the compounds found to be of chemopreventive and therapeutic importance are summarized in Table 1. Complete inhibition of cancer induction has been detected in ursodeoxycholic, polyethylene glycol (PEG), methylmethanethiosulfonate (MMTS) treated rats and in rats given exercise. Also, celecoxib, acetoxychavicol, selenium, p53 vaccination, piroxicam with difluoromethylornithine (DFMO), cellulose, aspirin, S-allylcysteine, obacunone, sulindac sulfone and hesperidin (flavanone glycoside) reduced the incidence of adenocarcinoma more than 78\% (Corpet et al., 2008). Moreover, a DMBDD (7-hydroxy-7'-methoxy-4,4'- 


\begin{tabular}{|c|c|c|}
\hline Rat model & Name of the compound & Reference \\
\hline $\begin{array}{l}\text { Azoxymethane }(\mathrm{AOM}) \\
\text { /Dimethylhydrazine } \\
\text { model }\end{array}$ & $\begin{array}{l}\text { Etoricoxib (selective COX-2 inhibitor) } \\
\text { Diclofenac (preferential COX-2 inhibitor) } \\
\text { Adlay bran ethanol extract (ABE-Ea) } \\
\text { Soy isoflavones } \\
\text { Arabinoxylan-oligosaccharide } \\
\text { Probiotic soy products } \\
\text { Physical exercise } \\
\text { Astaxanthine } \\
\text { Soy isoflavones } \\
\text { R-Flurbiprofen } \\
\text { Copper-indomethacin } \\
\text { Naproxen } \\
\text { Nitric Oxide-Naproxen } \\
\text { CP-31398 (a p53 modulator) } \\
\text { Celecoxib } \\
\text { Symbiotic association of Bifidobacterium } \\
\text { lactis and carbohydrate 'resistant starch } \\
\text { Melatonin } \\
\text { Prebiotic germinated barley foodstuff (GBF) } \\
\text { High amylose maize starch and butyrylated } \\
\text { high amylose maize starch }\end{array}$ & $\begin{array}{l}\text { (Kaur Saini \&Nath } \\
\text { Sanyal, 2010) } \\
\text { (Kaur Saini \&Nath } \\
\text { Sanyal, 2010) } \\
\text { (Chung et al., 2010) } \\
\text { (Min et al., 2010) } \\
\text { (Femia et al., 2010) } \\
\text { (Silva et al., 2009) } \\
\text { (Silva et al., 2009) } \\
\text { (Prabhu et al., 2009) } \\
\text { (Raju et al., 2009) } \\
\text { (Martin et al., 2010) } \\
\text { (Bonin et al., 2010) } \\
\text { (Steele et al., 2009) } \\
\text { (Steele et al., 2009) } \\
\text { (Rao et al., 2009) } \\
\text { (Rao et al., 2009) } \\
\text { (Le Leu et al., 2010) } \\
\text { (Tanaka et al., 2003) } \\
\text { (Kanauchi et al., } \\
\text { 2008) } \\
\text { (Clarke et al., 2008) }\end{array}$ \\
\hline MNU model & TAC-101 (a retinobenzoic acid derivative) & $\begin{array}{l}\text { (Nakayama et al., } \\
\text { 2009) }\end{array}$ \\
\hline DMBDD model & $\begin{array}{l}\text { PJJ-34 (13 alpha, 14alpha-epoxy-3beta- } \\
\text { methoxyserratan-21 beta-ol), a triterpenoid }\end{array}$ & (Doi et al., 2010) \\
\hline Orthotropic model & $\begin{array}{l}\text { Combined use of bevacizumab and } \\
\text { irinotecan (CPT-11) as postoperative } \\
\text { adjuvant chemotherapy }\end{array}$ & (Mizobe et al., 2008) \\
\hline $\begin{array}{l}\text { AOM model or } \\
\text { Dimethylhydrazine } \\
\text { model }\end{array}$ & $\begin{array}{l}\text { Combinatorial therapy using HMG-CoA } \\
\text { reductase inhibitor (HRI) lovastatin (LOV) } \\
\text { and the selective apoptotic antineoplastic } \\
\text { drug (SAAND) exisulind (EXS) } \\
\text { Ursodeoxycholic acid (UDCA) } \\
\text { Protective effect of Fullerenol on heart and } \\
\text { liver toxicity induced by doxorubicin }\end{array}$ & $\begin{array}{l}\text { (Hess et al., 2004) } \\
\text { (Injac et al., 2009) }\end{array}$ \\
\hline
\end{tabular}

Table 1. Rat models used in chemoprevention \& chemotherapy. 
bis(1,3-benzodioxole)-5,5'-dicarboxylic acid dimethyl ester) rat multiorgan carcinogenicity model has also been developed for carcinogen testing (Takahashi et al., 1992; Imaida et al., 2003). The DMBDD model can be used for prediction of intestinal carcinogenesis risk assessment as well as for chemoprevention studies.

\subsection{Mouse models}

\subsubsection{APC related models}

The first heritable mouse model of colon cancer, APCMin/+, was reported in 1990 as a result of ethylnitrosourea (ENU)-induced germline truncating mutation at the codon 850 of APC (Moser et al., 1990, 1992; Su et al., 1992). In the C57BL/6J mouse background APCMin/+ mice develop about 30 small intestinal polyps with occasional adenocarcinoma and essentially no tumor in the colon (McCart et al., 2008). Although this contrasts human FAP (familial adenomatous polyposis) where most of the adenomas are in the colon and these adenomas certainly progresses to invasive adenocarcinoma, the APCMin/+ models due to their phenotypic and histopathological similarities to human intestinal neoplasm are used not only to test therapeutic and chemopreventive interventions but also to understand the role of APC gene in CRC (Fodde \& Smits, 2001). The APCMin/+ models also proved to be important for the study of genetic modifiers-of-Min (Mom) locus. When APCMin/+ C57BL/6J mice were crossed to AKR and MA mice, only 6 to 7 intestinal adenomas were observed and backcrossing F1 hybrids to the C57BL/6J helped identify a number of loci modifying number and distribution of adenomas (Moser et al., 1992; Gould et al., 1996; Fodde \& Smits, 2001). The adenomas in the small intestine of the $\mathrm{APCMin}^{+}$mouse have dysplastic and hyperplastic crypts and villi but the colonic tumors are spherical and peduncular with dysplastic cells. Importantly, these adenomas display higher mitotic index than surrounding normal crypts (Kwong \& Dove, 2009). The Min mice due to their many advantages have been extensively used by scientists to study molecular pathogenesis of CRC - i] Min mice contains a single genetic change that produces a organ-specific, consistent, and discrete tumor phenotype, ii] Adenomas in Min mice develop rapidly, with lesions visible as early as 60 days, iii] high tumor multiplicities ( $>100$ /intestinal tract) providing strong statistical power, and iv] multiple pathways impacting tumorigenesis enable many entry points for basic or applied study (Kwong \& Dove, 2009). Importantly, other mouse models with targeted genetic manipulations at different locations on APC have also been generated (summarized in Table 2). When heterozygous, the $\Delta 474, \Delta 14, \Delta 716$, lacZ, and $\Delta 1309$ mouse models show phenotypes similar to that of Min (Sasai et al., 2000; Oshima et al., 2001; Niho et al., 2003; Colnot et al., 2004). In contrast, heterozygosity for the $1638 \mathrm{~N}$ allele results in $0-2$ tumors (none in the colon) while the 1638T model is tumor-free and unlike any other truncating allele, $1638 \mathrm{~T}$ homozygous is viable. The $1638 \mathrm{~N}$ has only approximately $1-2 \%$ of the truncated protein and is referred to as leaky allele (Fodde \& Smits, 2001). In contrast, $1638 \mathrm{~T}$ has the full expression level of the truncated protein and is known as truncated allele. Furthermore, Li Q et al., (2005) inserted a neomycin cassette in either orientation (reverse (neoR) or forward (neoF)) into the $13^{\text {th }}$ intron of APC to generate full-length hypomorphic (expression reduced to 10-20\%) alleles and showed that these heterozygous mice developed fewer than two adenomas per mouse ( $\mathrm{Li}$ et al., 2005). The Cre/loxP conditional gene targeting system is developed to generate additional APC models to induce tumors specifically in the colon (Shibata et al., 1997; Colnot et al., 2004; Gounari et al., 2005; Hinoi et al., 2007). 


\begin{tabular}{|c|c|c|c|c|c|c|}
\hline $\begin{array}{l}\text { Allele/trunc } \\
\text { ation } \\
\text { location }\end{array}$ & $\begin{array}{l}\text { Average } \\
\text { life- } \\
\text { span }\end{array}$ & $\begin{array}{l}\text { Genetic } \\
\text { back- } \\
\text { ground }\end{array}$ & $\begin{array}{l}\text { Homozyg } \\
\text { ous } \\
\text { pheno- } \\
\text { type }\end{array}$ & $\begin{array}{l}\text { Heterozygous } \\
\text { phenotype }\end{array}$ & $\begin{array}{l}\text { Average } \\
\text { no. of } \\
\text { spontaneo } \\
\text { us tumors } \\
\end{array}$ & References \\
\hline Min/850 & $\begin{array}{l}4-6 \\
\text { months }\end{array}$ & C57BL/6J & $\begin{array}{l}\text { Embryonic } \\
\text { lethality }\end{array}$ & $\begin{array}{l}\text { Multiple adenoma } \\
\text { in GI-tract (mainly } \\
\text { small intestine) }\end{array}$ & $50-70$ & $\begin{array}{l}\text { (Moser et al., } \\
\text { 1990; } \\
\text { Su et al., 1992) }\end{array}$ \\
\hline Min/850 & $3-5$ & BTBR/Pas & $\begin{array}{l}\text { Embryonic } \\
\text { lethality }\end{array}$ & $\begin{array}{l}\text { Multiple adenoma } \\
\text { in GI-tract (mainly } \\
\text { small intestine) }\end{array}$ & Up to 600 & $\begin{array}{l}\text { (Kwong } \\
\text { et al., 2007) }\end{array}$ \\
\hline$\Delta 716 / 716$ & $\begin{array}{l}5-7 \\
\text { months }\end{array}$ & C57BL/6J & $\begin{array}{l}\text { Embryonic } \\
\text { lethality }\end{array}$ & $\begin{array}{l}\text { Multiple adenoma } \\
\text { in GI-tract }\end{array}$ & Up to 300 & $\begin{array}{l}\text { (Oshima } \\
\text { et al., 1995) }\end{array}$ \\
\hline $\begin{array}{l}580 S / 580^{*} \\
\text { (based on } \\
\text { Cre-LoxP } \\
\text { recombinatio } \\
\text { n system) }\end{array}$ & $\mathrm{N} / \mathrm{A}$ & Mixed & $\mathrm{N} / \mathrm{A}$ & N/A & $\begin{array}{l}\text { No tumor } \\
\text { up to 1year } \\
\text { of age }\end{array}$ & $\begin{array}{l}\text { (Shibata } \\
\text { et al., 1997) }\end{array}$ \\
\hline $580 \mathrm{D} / 580^{*}$ & $\mathrm{~N} / \mathrm{A}$ & Mixed & $\begin{array}{l}\text { Embryonic } \\
\text { lethality }\end{array}$ & $\begin{array}{l}\text { Multiple } \\
\text { adenomas at } 4 \\
\text { week after } \\
\text { conditional } \\
\text { deletion }\end{array}$ & $7-10$ & $\begin{array}{l}\text { (Shibata } \\
\text { et al., 1997) }\end{array}$ \\
\hline $1638 \mathrm{~N} / 1638$ & $>1$ Year & C57BL/6J & $\begin{array}{l}\text { Embryonic } \\
\text { lethality }\end{array}$ & $\begin{array}{l}\text { Adenoma and } \\
\text { adenocarcinomas } \\
\text { in GI-tract, } \\
\text { desmoids tumors }\end{array}$ & $3-4$ & $\begin{array}{l}\text { (Fodde } \\
\text { et al., 1994) }\end{array}$ \\
\hline $1638 \mathrm{~T} / 1638$ & $\begin{array}{l}\text { Up to } 2 \\
\text { Years }\end{array}$ & C57BL/6J & Viable & Normal & 0 & $\begin{array}{l}\text { (Smits } \\
\text { et al., 1999) }\end{array}$ \\
\hline$\Delta 474 / 474$ & $\begin{array}{l}<6 \\
\text { months }\end{array}$ & C57BL/6J & $\begin{array}{l}\text { Embryonic } \\
\text { lethality }\end{array}$ & $\begin{array}{l}\text { Develops tumor } \\
\text { mainly in small } \\
\text { intestine, but also } \\
\text { in colon and } \\
\text { stomach }\end{array}$ & 120 & $\begin{array}{l}\text { (Sasai } \\
\text { et al., 2000) }\end{array}$ \\
\hline$\Delta 1309 / 1309$ & $\mathrm{~N} / \mathrm{R}$ & C57BL/6J & $\mathrm{N} / \mathrm{R}$ & & $25-40$ & (Niho et al., 2003) \\
\hline$\Delta 14 / 580^{*}$ & $\mathrm{~N} / \mathrm{A}$ & C57BL/6J & N/A & $\begin{array}{l}\text { Multiple } \\
\text { adenomas }\end{array}$ & $40-50$ & $\begin{array}{l}\text { (Colnot } \\
\text { et al., 2004) }\end{array}$ \\
\hline$\Delta 468 / 468$ & $\mathrm{~N} / \mathrm{R}$ & $\mathrm{N} / \mathrm{R}$ & $\begin{array}{l}\text { Embryonic } \\
\text { lethality }\end{array}$ & $\begin{array}{l}\text { Polyps starting } \\
\text { after } 2 \text { months of } \\
\text { age }\end{array}$ & $\mathrm{N} / \mathrm{R}$ & $\begin{array}{l}\text { (Gounari } \\
\text { et al., 2005) }\end{array}$ \\
\hline $\begin{array}{l}\text { Ex13NeoR/ } \\
\text { Full-length }\end{array}$ & $\begin{array}{l}>15 \\
\text { months }\end{array}$ & C57BL/6J & $\mathrm{N} / \mathrm{R}$ & $\begin{array}{l}\text { Small } \\
\text { microadenoma }\end{array}$ & 1.1 & (Li et al., 2005) \\
\hline $\begin{array}{l}\text { Ex13NeoF/ } \\
\text { Full-length }\end{array}$ & \begin{tabular}{|l}
$>15$ \\
months
\end{tabular} & C57BL/6J & $\mathrm{N} / \mathrm{R}$ & $\begin{array}{l}\text { Small } \\
\text { microadenoma }\end{array}$ & 0.3 & (Li et al., 2005) \\
\hline
\end{tabular}

*Conditional expression; N/A=Not applicable; $\mathrm{N} / \mathrm{R}=$ Not reported

Table 2. Adematous polyposis coli (APC) based intestinal tumor models 
Because APCMin/+ mice rarely develop invasive cancer, efforts were made to develop compound mouse models by introducing alterations of genes known to be involved in CRC signaling pathways and produce invasive tumors mimicking human disease. The oncogene Kras, which is mutated in $40-50 \%$ of human CRC, is not altered in APCMin/+ polyps and the $\mathrm{APC}^{\mathrm{Min} /+}$ mice with the introduction of Kras develop aggressive adenocarcinoma (Fodde \& Smits, 2001). Loss of EphB receptor is an important event in the progression of CRC and APCMin/+ carrying a dominant negative EphB2 transgene showed 10 fold more tumor formation with greater number of invasive adenocarcinomas (Fodde \& Smits, 2001; Batlle et al., 2005). The APCMin/+ mouse model has been quite useful as an experimental system for studying colorectal tumorigenesis and CRC chemoprevention strategies (Moser et al., 1990) because Min mice have two distinct advantages i] numerous adenomas with the same inherited APC mutation are available for analysis and ii] these adenomas develop in animals of uniform genetic background (Luongo et al., 1994).

\subsubsection{Mismatch repair (MMR) deficient models}

The HNPCC (hereditary nonpolyposis colorectal cancer) is an inherited condition with inactivated DNA mismatch repair (MMR) genes, like MLH1, MSH2, MSH6, and PMS2 (Fishel et al., 1993; Lynch \& de la Chapelle, 2003) and leads to the development of a variety of cancers including that of the colon (Lynch \& Smyrk, 1996). Mouse models with loss of function of MMR genes have been generated and mice lacking Mlh1, Msh2 and Msh6 develop tumors in stomach, small intestine, and colon. However, these mice also develop cancers of the lymphatic system, skin and lung (Reitmair et al., 1996; Edelmann et al., 1997, 1999, 2000). Enhanced development of adenomas was observed in the APCMin/+ mice lacking Msh2 with increase in colonic adenoma numbers. Interestingly, these mice show normal growth and can reproduce but have reduced life span (Reitmair et al., 1996). Although loss of Msh3 is not associated with increased tumors, loss of both the Msh3 and Msh6 leads to an increase in GI tumors at a younger age, similar to Mlh1 or Msh2-deficient mice (Edelmann et al., 2000). Mice bearing mutations in the Msh6 gene have a life span of 18 months and develop GI tumors within one year. The MMR mouse models carrying one functional copy of APC showed increasing mutation of APC and an enhanced frequency of intestinal neoplasia (Reitmair et al., 1996; Kuraguchi et al., 2001). Furthermore, mice lacking Mlh1 in APC1638N model have a 40-fold increase in adenomas compared to APC1638N mice alone (Edelmann et al., 1999). Interestingly, the PMS2 $/-$ mice are vulnerable to lymphomas but they do not develop GI tumors. However, the PMS2-/- mice in APCMin background showed an increased number of adenomas in the GI-tract compared to Min alone (Prolla et al., 1998; Prolla, 1998; Baker et al., 1995). In contrast, the Mlh1/APC1638N mice showed a greater percentage of tumors progressed to invasive carcinomas (Edelmann et al., 1999). The MMR models are useful for screening of agents known to interfere with DNA mismatch repair processes for their therapeutic or carcinogenic effects.

\subsubsection{TGF- $\beta$ models}

The TGF- $\beta$ (transforming growth factor- $\beta$ ) signaling pathway regulates a number of cellular processes including cellular differentiation, growth suppression, deposition of extracellular matrix and apoptosis (Figure 1). The TGF ligands through a heteromeric receptor mediate their effects on cells and dysregulation of the TGF- $\beta$ receptor 2 (TGF- $\beta$ R2) is the most common occurrence in the CRC (Bellam \& Pasche, 2010; Grady et al., 1999). Although TGF $\beta R 2$ has been suggested to have a tumor suppressor function in CRC, recent reports indicate that it could act as a tumor suppressor as well as a tumor promoter (Tang et al., 1998; 


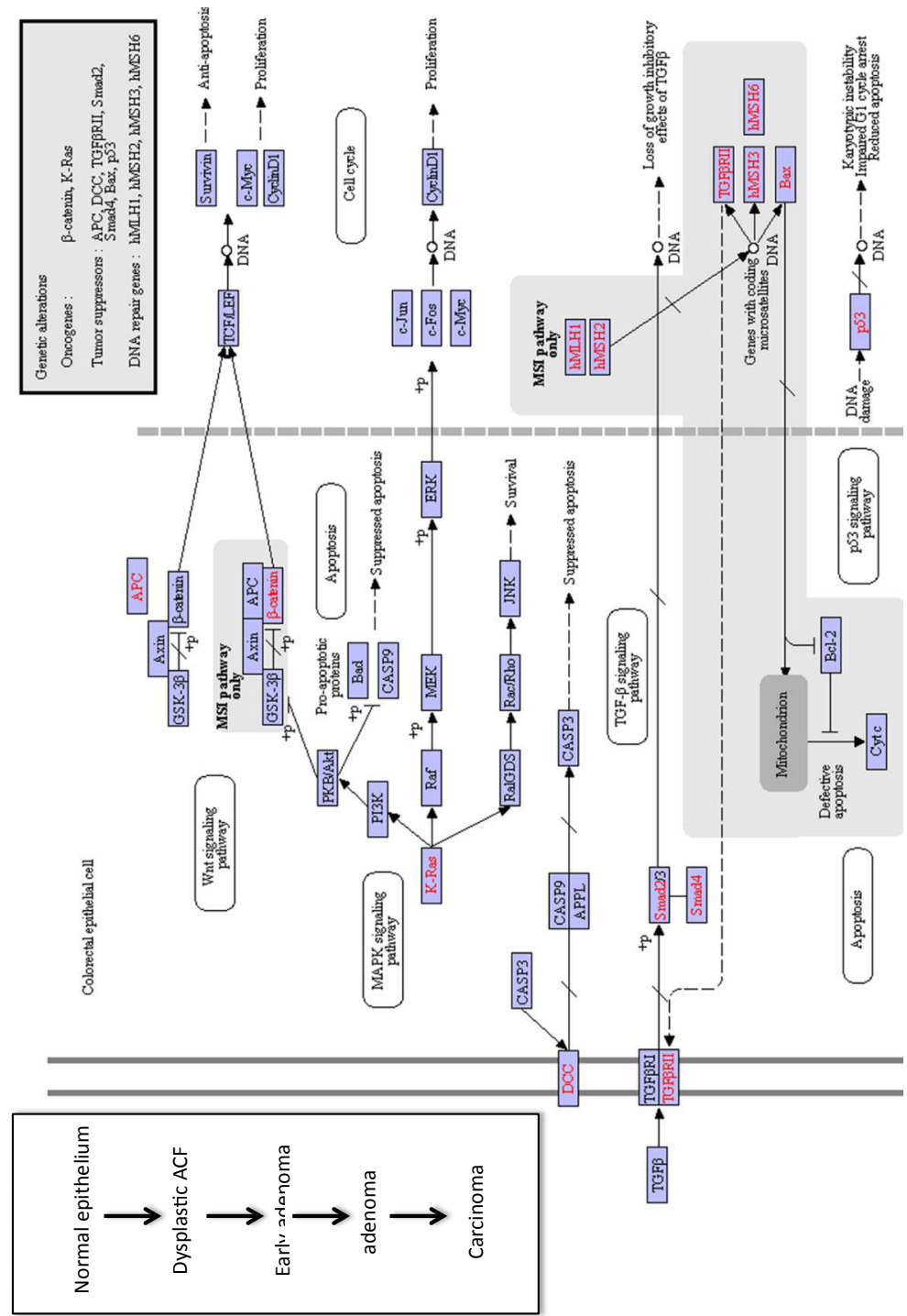

Fig. 1. Integrated molecular pathway implicated in development of colorectal cancer (Courtesy: KEGG pathway, www.genome.jp/kegg). Alterations in Wnt signaling including Wnt, APC, Axin and TCFs are associated increased $\beta$-catenin level and increased cell proliferation. The MAPK signaling is associated with the oncogenic activation of RAS and ERK signaling leading to increase cell proliferation). The TGF- $\beta$ pathway is mainly a growth inhibitory pathway and any perturbations leads to suppressed apoptosis and increased cell proliferation. The mismatch repair (MMR) pathway maintains DNA homeostasis by facilitating post-replication repair and dysfunction results in accumulation of potential mutations and genetic instability implicated in the development of CRC. Important candidate proteins altered in CRC are highlighted in red color. 
Yang et al., 2002a, b; Blobe et al., 2000). Mouse models related to the TGF- $\beta$ pathway have been used to delineate the multifaceted role of this pathway during colorectal carcinogenesis. It has been reported that the TGF- $\beta 1$ deficient mice due to widespread inflammation die around three weeks of age (Shull et al., 1992; Kulkarni \& Karlsson, 1993). Importantly, in the absence of Rag2 the TGF- $\beta 1$-deficient mice survive until adulthood (Diebold et al., 1995). Due to the significant incidence of carcinoma of the cecum and colon in these mice, the Rag2/TGF- $\beta 1$ deficient mice remains a useful model to study the role of inflammation in CRC in relation to the TGF 31 signaling (Engle et al., 1999; Maggio-Price et al., 2006). Mouse lacking TGF- $\beta 2$ in the colonic epithelium showed increased adenoma and adenocarcinoma formation after carcinogen treatment. Apart from TGF- $\beta$, mouse models representing alterations in the other factors in this important pathway like SMAD2, SMAD4 and SMAD3 have been reported. (Eppert et al., 1996). Although mice lacking SMAD2 and SMAD4 are embryonically lethal, the SMAD3 deficient mice are viable and are a useful model of CRC (Zhu et al., 1998). Importance of the TGF- $\beta$ related models lies in the fact that the APC remains intact in the adenomas of these mice and these models could serve as a valuable tool to investigate non-WNT/APC/ $\beta$ catenin-mediated colorectal carcinogenesis (Kaiser et al., 2007). Interestingly, the TGF- $\beta$ related models in the APCMin/+ background showed increased incidence of invasive carcinoma specifically in the distal colon (Takaku et al., 1998; Sodir et al., 2006).

\subsubsection{Inflammation mediated models}

Inflammatory bowel diseases (IBD) like ulcerative colitis (UC) and Crohn's Disease are predisposing conditions of CRC (Itzkowitz \& Harpaz, 2004; Itzkowitz \& Yio, 2004). Prolonged administration of dextransulfate sodium (DSS) in mice resulting in chronic colitis and formation of high-grade dysplasia confirmed the involvement of chronic inflammation in colorectal carcinogenesis (Okayasu et al., 1990). Interestingly intestinal tumorigenesis was augmented by combined administration of AOM and DSS. (Tanaka et al., 2003). To demonstrate that deficiency of Sigirr (single immunoglobulin and tollinterleukin 1 receptor domain) along with bacteria-induced inflammation increases susceptibility to CRC investigators effectively utilized the combined AOM/DSS model (Wald et al., 2003; Xiao et al., 2007; Uronis \& Threadgill, 2009). Furthermore, the combined AOM/DSS model was also an important instrument in defining the role of the JAK/STAT (Janus kinase/signal transducers and activators of transcription) and NFkB (nuclear factor of kappa light chain gene enhancer in B-cells) pathways in inflammation-induced CRC (Wirtz \& Neurath, 2007). The role of the JAK/STAT pathway in colorectal carcinogenesis was further confirmed by the fact that dysfunctional Socs1 and Socs3 (suppressors of cytokine signaling) leads to enhanced activation of STAT1, STAT3 and NFkB and subsequent growth of colorectal tumors (Hanada et al., 2006). Although lack of only Socs3 in the intestinal epithelial cells is not associated with chronic inflammation or tumor formation, these mice when treated with AOM/DSS showed distinct inflammatory response followed by colonic tumors (Hanada et al., 2006; Rigby et al., 2007). In contrast to increased nuclear $\beta$-catenin in the Socs3 deficient mice, the colorectal tumors in Socs1 deficient mice display enhanced expression of Myc (Sutherland et al., 2006). In addition, the Muc2 $\%$ is an important animal model to study the role of inflammation in the colorectal carcinogenesis. This model specifically targets mucin-forming Muc2 and unlike other models tumor formation is also observed in the rectum (Mack \& Hollingsworth, 1994; Yang et al., 2005; Femia et al., 2009). 


\subsubsection{Immune system related models}

Models have been developed to investigate the role of immune system in colorectal carcinogenesis. Immune cells are involved in inflammatory response and inflammation is intimately related to CRC. Therefore, the IL-2 (interleukin-2), IL-10, and TCR $\alpha$ knockout models were developed and used in studying role of diet and inflammation in colorectal cancer initiation and progression. (Rudolph et al., 1995; Kullberg et al., 1998; Mizoguchi et al., 2000; Seril et al., 2005).

\subsubsection{Carcinogen-induced models}

Although important information on familial and sporadic colorectal carcinogenesis was obtained from genetic animal models, it is the carcinogen-induced animal models that were instrumental in delineating molecular events specifically in the sporadic CRC. It is worth mentioning that the colon-specific carcinogen dimethylhyrdrazine (DMH) along with AOM has been useful in developing our current understanding of the molecular mechanisms underlying sporadic colorectal carcinogenesis (Druckrey et al., 1966). To its advantage the carcinogen-induced mouse model develops tumor which show much similarities to the pathophysiology of the human CRC (Kaiser et al., 2007; Uronis et al., 2007). The carcinogenmediated tumors show alterations in the WNT/ $\beta$-catenin pathway (Takahashi et al., 2000). Interestingly, the AOM-induced colorectal carcinogenesis, unlike in the APCMin/+, is mainly due to the mutations in the Ctnnb1 gene, which encodes $\beta$-catenin protein. Mutations in the Ctnnb1 results in ubiquitination-resistant stabilization of the $\beta$-catenin leading to growth of colorectal adenomas associated with upregulation of proliferation markers like cyclin D1 and cMyc (Wang et al., 1998; Kaiser et al., 2007). The carcinogen-induced model was also a key player in the identification of the modifier loci like the Ptprj (a receptor-type protein tyrosine phosphatase), which has been shown to modify susceptibility to DMH and has shown frequent loss of heterozygosity in human colon cancer (Ruivenkamp et al., 2002). Additionally, the carcinogen-induced models led to the recognition of Pref1 as a modifier of CRC and the promoter of the Pref1 is suggested to contain a $\beta$-catenin/TCF response element (Dong et al., 2004; Ruivenkamp et al., 2002; Uronis et al., 2007).

\subsubsection{Mouse models in chemoprevention and therapeutics development}

The genetic mouse models as well as the carcinogen-induced models of CRC (APC, TGF- $\beta$ and mismatch repair based models) are used to evaluate the effect of diets and chemopreventive agents. The chemopreventive and dietary interventions are usually started between 3 and 6 weeks of age and invariably the principal biological endpoint is the number and grade of the tumors. It is important to note that in contrast to human CRC where no small intestinal tumors are observed, the tumors in the mutant models are mostly in the small intestine. However, the concept that the non-steroidal anti-inflammatory drugs (NSAID) have a chemopreventive role in the CRC was first established in these models showing reduction in tumor number in the small intestine. The chemopreventive properties of NSAIDs like celecoxib and piroxicam were also validated in the carcinogen-induced models showing decrease in polyp number and size. Due to commercial availability, the $\mathrm{APCMin/+}^{+}$is the model of choice in many studies and a list of agents screened in APCMin/+ mouse model is shown in Table 3. Most of the other CRC mouse models are used for specific biological end points. But a few of them such as APC1638N model because of its longer life span and good signal to noise ratio is used for carcinogen testing and is suggested to be more useful than APCMin/+ mice (Trani et al., 2010). 


\begin{tabular}{|c|c|}
\hline Name of compound & References \\
\hline Aspirin & (Barnes\&Lee, 1998) \\
\hline Piroxicam & (Ritland\&Gendler, 1999) \\
\hline Phenanthridinone derivative (PJ 34) & (Mabley et al., 2004) \\
\hline Non-steroidal anti-inflammatory drugs (NSAIDs) & (Gescher, 2004) \\
\hline $\begin{array}{l}\text { DMU-135 (3-4 methylenedioxy-3'4' } 4^{\prime} \text {-trimethoxy } \\
\text { chalcone), a potent tyrosine kinase inhibitor prodrug }\end{array}$ & (Sale et al., 2006) \\
\hline Atorvastatin & (Swamy et al., 2006) \\
\hline Celecoxib & (Swamy et al., 2006) \\
\hline Sulforaphane (Isothiocynate compound) & (Khor et al., 2006) \\
\hline Anthocyanin & (Bobe et al., 2006) \\
\hline Difluoro methylornithine (DFMO) & (Telang\&Katdare, 2007) \\
\hline Epigallocatechin 3- gallate (EGCG) & (Telang\&Katdare, 2007) \\
\hline Dibenzoylmethane & (Tammariello\&Milner, 2010) \\
\hline PPAR ligand MCC-555 & (Yamaguchi et al., 2008) \\
\hline Metformin & (Tomimoto et al., 2008) \\
\hline $\begin{array}{l}\text { Alpha-phenyl-tert-butyl-nitrone (PBN) and } 4 \\
\text { hydroxy-PBN }\end{array}$ & (Floyd et al., 2010) \\
\hline Chafuroside & (Tammariello\&Milner, 2010) \\
\hline Sodium Taurocholate & (Smith et al., 2010) \\
\hline COX-2 inhibitors & (Nakanishi et al., 2011) \\
\hline $\begin{array}{l}\text { Scopolamine butylbromide (muscarinic receptor } \\
\text { antagonist) }\end{array}$ & (Raufman et al., 2011) \\
\hline Curcumin & (Murphy et al., 2011) \\
\hline Silibinin & (Rajamanickam et al., 2010) \\
\hline Ellagic acid & (Mutanen et al., 2008) \\
\hline Epigallocatechin gallate (EGCG) & (Telang\&Katdare, 2007) \\
\hline Dietary sphingolipids & (Symolon et al., 2004) \\
\hline Dietary Folate & (Song et al., 2000) \\
\hline Dietary isoflavones & (Sorensen et al., 1998) \\
\hline Apple polyphenol extract (APE) & (Fini et al., 2011) \\
\hline Grape Seed extract (GSE) & (Velmurugan et al., 2010) \\
\hline Berries (bilberry, lingonberry, cloudberry) & (Mutanen et al., 2008) \\
\hline Green tea & (Issa et al., 2007) \\
\hline Orange peel extract (OPE) & (Fan et al., 2007) \\
\hline Anthocyanin rich tart cherry extract & (Bobe et al., 2006) \\
\hline Fermented brown rice and rice bran & (Phutthaphadoong et al., 2010) \\
\hline Fish oil & (Bose et al., 2007) \\
\hline Dietary / caloric restriction & (Tammariello\&Milner, 2010) \\
\hline Exercise/physical activity & (Baltgalvis et al., 2008) \\
\hline
\end{tabular}

Table 3. Use of APCMin/+ mouse model in chemoprevention development. 


\subsection{Xenograft models of colon cancer}

Colon cancer xenograft models are created by implantation of cells subcutaneously, intrasplenically, or into the renal capsule. It is important to implant the xenograft into the immunocompromised mice and commonly the T-cell deficient "nude" mice or NOD-SCID (non-obese diabetic/severe combined immunodeficiency) mice are used (Rygaard \& Povlsen, 1969). The xenograft models of CRC are commonly used to assess newer therapeutics and understand the pathogenesis of human disease. Indeed, subcutaneous xenografts have found an important place in CRC research due to the fact that anesthetics are not required and the tumors are accessible for external measurement. Some of the disadvantages of the subcutaneous model are i] lack of tumor microenvironment representative of the $\mathrm{CRC}$, and ii] in contrast to the $>50 \%$ hepatic metastatic incidence of CRC, no metastasis is observed in the subcutaneous xenograft models. However, xenograft models involving intrasplenic or intra-renal-capsule, although have shown metastasis similar to human CRC, does not represent tumor microenvironment of CRC and signaling pathway could be different than the human disease (Furukawa et al., 1993; Fidler, 1991a, b, c). Consequently, implantation of CRC xenografts into mouse colon, the orthotopic model, is much preferred by the investigators due to their similar characteristics of the human ailment.

\subsection{Orthotopic mouse model}

An orthotopic mouse model involves placing of colorectal cancer cell or tumor tissue into the intestinal sub-mucosa (Tseng et al., 2007). The orthotopic model, unlike the subcutaneous model, is associated with all of the components of the tumor microenvironment as well as all of the angiogenic and growth factors, and cytokines. In addition to mimicking the human CRC in terms of metastasis and microenvironments, the orthotopic model also allows assessment of the alterations in the microenvironment on tumor initiation and progression. From a technical point of view, generation of orthotopic models demands specific expertise and more time than subcutaneous models. Because of technical difficulties in the physical measurement of the tumors, the orthotopic model also requires that an appropriate reporter like luciferase be in place for measuring tumor growth to determine the efficacy of a drug treatment. As with any animal model of human diseases there are inherent shortcoming and the orthotopic animal model is no exception. Because the tumors are in the colon, the orthotopic model requires sacrifice of the animals at a predetermined time for quantitative and qualitative analysis of the tumor. However, the orthotopic model has the advantage of mimicking human CRC including tumor microenvironment.

\section{Zebrafish - A non-murine model of colorectal cancer}

Signaling pathways involved in colorectal carcinogenesis are conserved across species and zebrafish, a well-characterized simple model system for human disease, are widely used to understand the molecular basis of cancer including CRC. Water borne carcinogens induce a wide variety of benign and malignant tumors in many organs of zebrafish. Zebrafish due to its easy maintainence and breeding along with conservation of human cancer-relevant oncogenes, and tumor suppressor and cell cycle genes makes it a useful model to study carcinogenesis. Interestingly, the zebrafish mutants display phenotypes similar to many human disorders, including cancer, cardiovascular disease, and neurodegeneration. Zebrafish carrying a mutation in the region representing most of the observed human APC 
mutations were identified recently and like murine models the heterozygous fish develop intestinal adenomas (12\%), which resembles its murine counterpart (Goessling et al., 2007). The APC-heterozygous fish when exposed to dimethylbenzanthracene, showed significant increase in the tumor number with $44 \%$ developing liver tumors and 35\% developing intestinal tumors and could serve as an important model system to screen carcinogens (Goessling et al., 2007).

\subsection{Zebrafish model in chemoprevention and therapy}

Zebrafish model is in use for the target selection, bioactive compound screening as well as in the drug toxicity and efficacy studies (Lieschke \& Currie, 2007). Angiogenesis supports cancer progression including CRC and anti-angiogenic therapy inhibits cancer growth. On the contrary anti-angiogenic therapy has been implicated in inflammation a known risk factor of colorectal carcinogenesis. Our understanding of the correlation between tumor angiogenesis, inflammation, and metastasis was much enhanced by studies in the zebrafish model (Moshal et al., 2010). Furthermore, the zebrafish model has been used to study potential therapeutic agents like SKLB610 (inhibitor of angiogenesis related tyrosine kinase), which was reported to inhibit angiogenesis in zebrafish sub-intestinal veins (Cao et al., 2011). The zebrafish model was useful in determining the role of DNA demthylase in maintaining intestinal epithelial cells lacking APC in an undifferentiated state (Rai et al., 2010). Additionally, it has been reported that the zebrafish expressing a truncated form of APC with either retinoic acid or a selective COX-2 inhibitor decreased $\beta$-catenin in the cell. Curcumin-loaded biodegradable polymeric micelles (Cur/MPEG-PCL) has been shown to efficiently block angiogenesis in transgenic zebrafish model (Gou et al., 2011). Similarly, the incorporation of doxorubicin in MPEG-PCL micelles enhanced the anticancer activity and decreased the systemic toxicity of doxorubicin in Zebrafish and has implications for CRC treatment (Lee et al., 2006).

\section{Animal models in chemoprevention and chemotherapeutics development}

Rodent models have been used for CRC research providing insight into the complex oncogenic events contributing to the loss of cell growth and differentiation control. These models also offer prospects to identify and study both therapeutic and chemopreventive agents. In general, almost all popular human colorectal cancer prevention strategies, from dietary manipulations (such as folate or calcium supplementation), to drug testing (such as (NSAIDs) have been evaluated in both carcinogen-induced and genetically modified animal models. In most cases, suppression of polyps has demonstrated the preventive effects of these strategies, and in some cases, investigators have been able to dissect pathways where these agents block the development of aberrant crypt foci (ACF). Moreover, approaches that are effective in preventing the early stages of colorectal tumorigenesis have been shown to actually promote tumor growth in later stages of the adenoma-carcinoma sequence. This type of observation in mice is important in polyp prevention studies in humans where folate supplementation may actually be harmful in subjects already predisposed to colorectal neoplasia. Although it is important to note that caution has to be exercised in extrapolating animal model data to human, at least studies with NSAID have shown similar protective effects both in human and animal. However, some differential response of chemopreventive drugs has been observed between animal studies and human response. This could be because of higher genetic homogeneity of mice compared to humans, physiologic differences 
in gut motility, hormones and immune surveillance, and differences in genetic events in somatic cells during adenoma to carcinoma transition in mouse compared to human colorectal neoplasia.

\section{Comparison of human data with animal model data}

With few exceptions, a significant correlation was observed between animal and human studies. Both the AOM rat model and the mutant mouse models supported the chemopreventive effects of the NSAID. This is supportive of the epidemiological studies proposing that, NSAIDs might reduce the colorectal cancer incidence by at least $45 \%$ in humans. Also supportive is the effects of celecoxib and sulindac shown to decrease the number of polyps in FAP patient trials. Similar to human data, rats and mice fed a high-fat diet showed increased adenomas than those fed a low-fat diet thus establishing the relationship between the colon cancer incidence and the intake of fat. Fatty diets with high linoleic acid content and n-6-polyunsaturated fatty acids seem to increase the number of tumors in rodents. Moreover, caloric reduction is a strategy that seems very efficient in animals. A reasonable agreement is observed between the results of these animal studies and the more limited clinical studies with few differences (Corpet \& Pierre, 2003).

\section{Limitations of animal models}

Currently a number of animal models are available to dissect various facets of CRC and to undertake risk estimation studies. Mutant mouse models provide a unique opportunity in studying numerous adenomas under defined experimental conditions and uniform genetic background. However, use of animal models in studying human disease has its own limitations. For example, in carcinogen-induced models of $C R C$, the tumor incidence and latency period could be modulated by amount of carcinogen used - higher amount of carcinogen leading to higher incidence of tumors. However, high ethanol consumption reduced carcinogen $(\mathrm{DMH})$-induced tumorigenesis suggesting that $\mathrm{DMH}$ model is not useful in determining the role of alcohol in CRC. This discrepancy was resolved using the APCMin/+ mice model where ethanol consumption was observed as a risk factor for CRC (Roy et al., 2002). Careful consideration is essential for the selection of animal model to study a particular agent and requires validation is two or more models for the unequivocal demonstration.

\section{Conclusions}

Future advances in animal model development will require combinations of dietary and genetic manipulation of rodents or other inexpensive animals to more accurately mimic the various factors that contribute to colorectal neoplasia in humans. As epidemiologic and molecular studies demonstrate the heterogeneity of colorectal tumor development in diverse populations (e.g. the microsatellite instability or CIMP pathways), it is expected that any one model will not answer all the questions about the CRC chemoprevention or therapeutic intervention strategies under investigation.

\section{Acknowledgment}

This work was supported by funding from NASA (Grant\#NNX09AU95G). 


\section{References}

Amos-Landgraf, JM.; Kwong, LN.; Kendziorski, CM.; Reichelderfer, M.; Torrealba, J.; Weichert, J.; Haag, JD.; Chen, KS.; Waller, JL.; Gould, MN. \& Dove, WF. (2007). A target-selected Apc-mutant rat kindred enhances the modeling of familial human colon cancer. Proc Natl Acad Sci U S A, 104, 4036-4041.

Baker, SM.; Bronner, CE.; Zhang, L.; Plug, AW.; Robatzek, M.; Warren, G.; Elliott, EA.; Yu, J.; Ashley, T.; Arnheim, N.; Flavell, RA. \& Liskay, RM. (1995). Male mice defective in the DNA mismatch repair gene PMS2 exhibit abnormal chromosome synapsis in meiosis. Cell, 82, 309-319.

Baltgalvis, KA.; Berger, FG.; Pena, MM.; Davis, JM. \& Carson, JA. (2008). Effect of exercise on biological pathways in ApcMin/+ mouse intestinal polyps. J Appl Physiol, 104, 1137-1143.

Barnes, CJ. \& Lee, M. (1998). Chemoprevention of spontaneous intestinal adenomas in the adenomatous polyposis coli Min mouse model with aspirin. Gastroenterology, 114, 873-877.

Batlle, E.; Bacani, J.; Begthel, H.; Jonkheer, S.; Gregorieff, A.; van de Born, M.; Malats, N.; Sancho, E.; Boon, E.; Pawson, T.; Gallinger, S.; Pals, S. \& Clevers, H. (2005). EphB receptor activity suppresses colorectal cancer progression. Nature, 435, 1126-1130.

Bellam, N. \& Pasche, B. (2010). Tgf-beta signaling alterations and colon cancer. Cancer Treat Res, 155, 85-103.

Blobe, GC.; Schiemann, WP. \& Lodish, HF. (2000). Role of transforming growth factor beta in human disease. N Engl J Med, 342, 1350-1358.

Bobe, G.; Wang, B.; Seeram, NP.; Nair, MG. \& Bourquin, LD. (2006). Dietary anthocyaninrich tart cherry extract inhibits intestinal tumorigenesis in APC(Min) mice fed suboptimal levels of sulindac. J Agric Food Chem, 54, 9322-9328.

Bonin, AM.; Yanez, JA.; Fukuda, C.; Teng, XW.; Dillon, CT.; Hambley, TW.; Lay, PA. \& Davies, NM. (2010). Inhibition of experimental colorectal cancer and reduction in renal and gastrointestinal toxicities by copper-indomethacin in rats. Cancer Chemother Pharmacol, 66, 755-764.

Bose, M.; Hao, X.; Ju, J.; Husain, A.; Park, S.; Lambert, JD. \& Yang, CS. (2007). Inhibition of tumorigenesis in ApcMin/+ mice by a combination of (-)-epigallocatechin-3-gallate and fish oil. J Agric Food Chem, 55, 7695-7700.

Cao, ZX.; Zheng, RL.; Lin, HJ.; Luo, SD.; Zhou, Y.; Xu, YZ.; Zeng, XX.; Wang, Z.; Zhou, LN.; Mao, YQ.; Yang, L.; Wei, YQ.; Yu, LT.; Yang, SY. \& Zhao, YL. (2011). SKLB610: A Novel Potential Inhibitor of Vascular Endothelial Growth Factor Receptor Tyrosine Kinases Inhibits Angiogenesis and Tumor Growth in Vivo. Cell Physiol Biochem, 27, 565-574.

Chung, CP.; Hsu, HY.; Huang, DW.; Hsu, HH.; Lin, JT.; Shih, CK. \& Chiang, W. (2010). Ethyl acetate fraction of adlay bran ethanolic extract inhibits oncogene expression and suppresses DMH-induced preneoplastic lesions of the colon in F344 rats through an anti-inflammatory pathway. J Agric Food Chem, 58, 7616-7623.

Clarke, JM.; Topping, DL.; Bird, AR.; Young, GP. \& Cobiac, L. (2008). Effects of highamylose maize starch and butyrylated high-amylose maize starch on azoxymethane-induced intestinal cancer in rats. Carcinogenesis, 29, 2190-2194.

Colnot, S.; Niwa-Kawakita, M.; Hamard, G.; Godard, C.; Le Plenier, S.; Houbron, C.; Romagnolo, B.; Berrebi, D.; Giovannini, M. \& Perret, C. (2004). Colorectal cancers in 
a new mouse model of familial adenomatous polyposis: influence of genetic and environmental modifiers. Lab Invest, 84, 1619-1630.

Corpet, DE. \& Pierre, F. (2003). Point: From animal models to prevention of colon cancer. Systematic review of chemoprevention in min mice and choice of the model system. Cancer Epidemiol Biomarkers Prev, 12, 391-400.

Corpet, DE. \& Pierre, F. (2005). How good are rodent models of carcinogenesis in predicting efficacy in humans? A systematic review and meta-analysis of colon chemoprevention in rats, mice and men. Eur J Cancer, 41, 1911-1922.

Corpet, DE.; Tache, S.; Archer, MC. \& Bruce, WR. (2008). Dehydroalanine and lysinoalanine in thermolyzed casein do not promote colon cancer in the rat. Food Chem Toxicol, 46, 3037-3042.

del Junco, GW. (2002). Pathology for Colon and Rectal Surgeons: web2.airmail.net/uthman/pdf_documents/colorect.pdf.

Diebold, RJ.; Eis, MJ.; Yin, M.; Ormsby, I.; Boivin, GP.; Darrow, BJ.; Saffitz, JE. \& Doetschman, T. (1995). Early-onset multifocal inflammation in the transforming growth factor beta 1-null mouse is lymphocyte mediated. Proc Natl Acad Sci U S A, 92, 12215-12219.

Doi, K.; Sakai, K.; Tanaka, R.; Toma, K.; Yamaguchi, T.; Wei, M.; Fukushima, S. \& Wanibuchi, H. (2010). Chemopreventive effects of 13alpha,14alpha-epoxy-3betamethoxyserratan-21beta-ol (PJJ-34), a serratane-type triterpenoid, in a rat multiorgan carcinogenesis bioassay. Cancer Lett, 289, 161-169.

Dong, M.; Guda, K.; Nambiar, PR.; Nakanishi, M.; Lichtler, AC.; Nishikawa, M.; Giardina, C. \& Rosenberg, DW. (2004). Azoxymethane-induced pre-adipocyte factor 1 (Pref-1) functions as a differentiation inhibitor in colonic epithelial cells. Carcinogenesis, 25, 2239-2246.

Druckrey, H.; Ivankovic, S. \& Preussmann, R. (1966). Teratogenic and carcinogenic effects in the offspring after single injection of ethylnitrosourea to pregnant rats. Nature, 210, 1378-1379.

Edelmann, W.; Cohen, PE.; Kneitz, B.; Winand, N.; Lia, M.; Heyer, J.; Kolodner, R.; Pollard, JW. \& Kucherlapati, R. (1999). Mammalian MutS homologue 5 is required for chromosome pairing in meiosis. Nat Genet, 21, 123-127.

Edelmann, W.; Umar, A.; Yang, K.; Heyer, J.; Kucherlapati, M.; Lia, M.; Kneitz, B.; Avdievich, E.; Fan, K.; Wong, E.; Crouse, G.; Kunkel, T.; Lipkin, M.; Kolodner, RD. \& Kucherlapati, R. (2000). The DNA mismatch repair genes Msh3 and Msh6 cooperate in intestinal tumor suppression. Cancer Res, 60, 803-807.

Edelmann, W.; Yang, K.; Kuraguchi, M.; Heyer, J.; Lia, M.; Kneitz, B.; Fan, K.; Brown, AM.; Lipkin, M. \& Kucherlapati, R. (1999). Tumorigenesis in Mlh1 and Mlh1/Apc1638N mutant mice. Cancer Res, 59, 1301-1307.

Edelmann, W.; Yang, K.; Umar, A.; Heyer, J.; Lau, K.; Fan, K.; Liedtke, W.; Cohen, PE.; Kane, MF.; Lipford, JR.; Yu, N.; Crouse, GF.; Pollard, JW.; Kunkel, T.; Lipkin, M.; Kolodner, R. \& Kucherlapati, R. (1997). Mutation in the mismatch repair gene Msh6 causes cancer susceptibility. Cell, 91, 467-477.

Engle, SJ.; Hoying, JB.; Boivin, GP.; Ormsby, I.; Gartside, PS. \& Doetschman, T. (1999). Transforming growth factor beta1 suppresses nonmetastatic colon cancer at an early stage of tumorigenesis. Cancer Res, 59, 3379-3386. 
Eppert, K.; Scherer, SW.; Ozcelik, H.; Pirone, R.; Hoodless, P.; Kim, H.; Tsui, LC.; Bapat, B.; Gallinger, S.; Andrulis, IL.; Thomsen, GH.; Wrana, JL. \& Attisano, L. (1996). MADR2 maps to 18q21 and encodes a TGFbeta-regulated MAD-related protein that is functionally mutated in colorectal carcinoma. Cell, 86, 543-552.

Fan, K.; Kurihara, N.; Abe, S.; Ho, CT.; Ghai, G. \& Yang, K. (2007). Chemopreventive effects of orange peel extract (OPE). I: OPE inhibits intestinal tumor growth in ApcMin/+ mice. J Med Food, 10, 11-17.

Femia, AP.; Dolara, P.; Luceri, C.; Salvadori, M. \& Caderni, G. (2009). Mucin-depleted foci show strong activation of inflammatory markers in 1,2-dimethylhydrazine-induced carcinogenesis and are promoted by the inflammatory agent sodium dextran sulfate. Int J Cancer, 125, 541-547.

Femia, AP.; Salvadori, M.; Broekaert, WF.; Francois, IE.; Delcour, JA.; Courtin, CM. \& Caderni, G. (2010). Arabinoxylan-oligosaccharides (AXOS) reduce preneoplastic lesions in the colon of rats treated with 1,2-dimethylhydrazine (DMH). Eur J Nutr, 49, 127-132.

Fidler, IJ. (1991a). New developments in in vivo models of neoplasia. Cancer Metastasis Rev, 10, 191-192.

Fidler, IJ. (1991b). Orthotopic implantation of human colon carcinomas into nude mice provides a valuable model for the biology and therapy of metastasis. Cancer Metastasis Rev, 10, 229-243.

Fidler, IJ. (1991c). The biology of cancer metastasis or, 'you cannot fix it if you do not know how it works'. Bioessays, 13, 551-554.

Fini, L.; Piazzi, G.; Daoud, Y.; Selgrad, M.; Maegawa, S.; Garcia, M.; Fogliano, V.; Romano, M.; Graziani, G.; Vitaglione, P.; Carmack, SW.; Gasbarrini, A.; Genta, RM.; Issa, JP.; Boland, CR. \& Ricciardiello, L. (2011). Chemoprevention of Intestinal Polyps in ApcMin/+ Mice Fed with Western or Balanced Diets by Drinking Annurca Apple Polyphenol Extract. Cancer Prev Res (Phila), 4, 907-915.

Fishel, R.; Lescoe, MK.; Rao, MR.; Copeland, NG.; Jenkins, NA.; Garber, J.; Kane, M. \& Kolodner, R. (1993). The human mutator gene homolog MSH2 and its association with hereditary nonpolyposis colon cancer. Cell, 75, 1027-1038.

Floyd, RA.; Towner, RA.; Wu, D.; Abbott, A.; Cranford, R.; Branch, D.; Guo, WX.; Foster, SB.; Jones, I.; Alam, R.; Moore, D.; Allen, T. \& Huycke, M. (2010). Anti-cancer activity of nitrones in the Apc(Min/+) model of colorectal cancer. Free Radic Res, 44, 108-117.

Fodde, R.; Edelmann, W.; Yang, K.; van Leeuwen, C.; Carlson, C.; Renault, B.; Breukel, C.; Alt, E.; Lipkin, M.; Khan, PM. \& et, a. (1994). A targeted chain-termination mutation in the mouse Apc gene results in multiple intestinal tumors. Proc Natl Acad Sci U S A, 91, 8969-8973.

Fodde, R. \& Smits, R. (2001). Disease model: familial adenomatous polyposis. Trends Mol $\mathrm{Med}, 7,369-373$.

Furukawa, T.; Kubota, T.; Watanabe, M.; Kuo, TH.; Nishibori, H.; Kase, S.; Saikawa, Y.; Tanino, H.; Teramoto, T.; Ishibiki, K. \& et, a. (1993). A metastatic model of human colon cancer constructed using cecal implantation of cancer tissue in nude mice. Surg Today, 23, 420-423.

Gerner, EW. (2007). Impact of dietary amino acids and polyamines on intestinal carcinogenesis and chemoprevention in mouse models. Biochem Soc Trans, 35, 322-325. 
Gescher, A. (2004). Polyphenolic phytochemicals versus non-steroidal anti-inflammatory drugs: which are better cancer chemopreventive agents? J Chemother, 16 Suppl 4, 3-6.

Goessling, W.; North, TE. \& Zon, LI. (2007). New waves of discovery: modeling cancer in zebrafish. J Clin Oncol, 25, 2473-2479.

Goodman, DG.; Ward, JM.; Squire, RA.; Paxton, MB.; Reichardt, WD.; Chu, KC. \& Linhart, MS. (1980). Neoplastic and nonneoplastic lesions in aging Osborne-Mendel rats. Toxicol Appl Pharmacol, 55, 433-447.

Gou, M.; Men, K.; Shi, H.; Xiang, M.; Zhang, J.; Song, J.; Long, J.; Wan, Y.; Luo, F.; Zhao, X. \& Qian, Z. (2011). Curcumin-loaded biodegradable polymeric micelles for colon cancer therapy in vitro and in vivo. Nanoscale, 3, 1558-1567.

Gould, KA.; Dietrich, WF.; Borenstein, N.; Lander, ES. \& Dove, WF. (1996). Mom1 is a semidominant modifier of intestinal adenoma size and multiplicity in Min/+ mice. Genetics, 144, 1769-1776.

Gounari, F.; Chang, R.; Cowan, J.; Guo, Z.; Dose, M.; Gounaris, E. \& Khazaie, K. (2005). Loss of adenomatous polyposis coli gene function disrupts thymic development. Nat Immunol, 6, 800-809.

Grady, WM.; Myeroff, LL.; Swinler, SE.; Rajput, A.; Thiagalingam, S.; Lutterbaugh, JD.; Neumann, A.; Brattain, MG.; Chang, J.; Kim, SJ.; Kinzler, KW.; Vogelstein, B.; Willson, JK. \& Markowitz, S. (1999). Mutational inactivation of transforming growth factor beta receptor type II in microsatellite stable colon cancers. Cancer Res, $59,320-324$.

Hanada, T.; Kobayashi, T.; Chinen, T.; Saeki, K.; Takaki, H.; Koga, K.; Minoda, Y.; Sanada, T.; Yoshioka, T.; Mimata, H.; Kato, S. \& Yoshimura, A. (2006). IFNgammadependent, spontaneous development of colorectal carcinomas in SOCS1-deficient mice. J Exp Med, 203, 1391-1397.

Hess, LM.; Krutzsch, MF.; Guillen, J.; Chow, HH.; Einspahr, J.; Batta, AK.; Salen, G.; Reid, ME.; Earnest, DL. \& Alberts, DS. (2004). Results of a phase I multiple-dose clinical study of ursodeoxycholic Acid. Cancer Epidemiol Biomarkers Prev, 13, 861-867.

Hinoi, T.; Akyol, A.; Theisen, BK.; Ferguson, DO.; Greenson, JK.; Williams, BO.; Cho, KR. \& Fearon, ER. (2007). Mouse model of colonic adenoma-carcinoma progression based on somatic Apc inactivation. Cancer Res, 67, 9721-9730.

Hu, R.; Khor, TO.; Shen, G.; Jeong, WS.; Hebbar, V.; Chen, C.; Xu, C.; Reddy, B.; Chada, K. \& Kong, AN. (2006). Cancer chemoprevention of intestinal polyposis in ApcMin/+ mice by sulforaphane, a natural product derived from cruciferous vegetable. Carcinogenesis, 27, 2038-2046.

Imaida, K.; Tamano, S.; Hagiwara, A.; Fukushima, S.; Shirai, T. \& Ito, N. (2003). Application of rat medium-term bioassays for detecting carcinogenic and modifying potentials of endocrine active substances. Pure Appl. Chem, 75, 2491-2495.

Injac, R.; Perse, M.; Cerne, M.; Potocnik, N.; Radic, N.; Govedarica, B.; Djordjevic, A.; Cerar, A. \& Strukelj, B. (2009). Protective effects of fullerenol $\mathrm{C} 60(\mathrm{OH}) 24$ against doxorubicin-induced cardiotoxicity and hepatotoxicity in rats with colorectal cancer. Biomaterials, 30, 1184-1196.

Issa, AY.; Volate, SR.; Muga, SJ.; Nitcheva, D.; Smith, T. \& Wargovich, MJ. (2007). Green tea selectively targets initial stages of intestinal carcinogenesis in the AOM-ApcMin mouse model. Carcinogenesis, 28, 1978-1984. 
Itzkowitz, SH. \& Harpaz, N. (2004). Diagnosis and management of dysplasia in patients with inflammatory bowel diseases. Gastroenterology, 126, 1634-1648.

Itzkowitz, SH. \& Yio, X. (2004). Inflammation and cancer IV. Colorectal cancer in inflammatory bowel disease: the role of inflammation. Am J Physiol Gastrointest Liver Physiol, 287, G7-17.

Kaiser, S.; Park, YK.; Franklin, JL.; Halberg, RB.; Yu, M.; Jessen, WJ.; Freudenberg, J.; Chen, X.; Haigis, K.; Jegga, AG.; Kong, S.; Sakthivel, B.; Xu, H.; Reichling, T.; Azhar, M.; Boivin, GP.; Roberts, RB.; Bissahoyo, AC.; Gonzales, F.; Bloom, GC.; Eschrich, S.; Carter, SL.; Aronow, JE.; Kleimeyer, J.; Kleimeyer, M.; Ramaswamy, V.; Settle, SH.; Boone, B.; Levy, S.; Graff, JM.; Doetschman, T.; Groden, J.; Dove, WF.; Threadgill, DW.; Yeatman, TJ.; Coffey, RJJ. \& Aronow, BJ. (2007). Transcriptional recapitulation and subversion of embryonic colon development by mouse colon tumor models and human colon cancer. Genome Biol, 8, R131.

Kanauchi, O.; Mitsuyama, K.; Andoh, A. \& Iwanaga, T. (2008). Modulation of intestinal environment by prebiotic germinated barley foodstuff prevents chemo-induced colonic carcinogenesis in rats. Oncol Rep, 20, 793-801.

Kaur Saini, M. \& Nath Sanyal, S. (2010). Evaluation of chemopreventive response of two cycloxygenase- 2 inhibitors, etoricoxib and diclofenac in rat colon cancer using FTIR and NMR spectroscopic techniques. Nutr Hosp, 25, 577-585.

Khor, TO.; Hu, R.; Shen, G.; Jeong, WS.; Hebbar, V.; Chen, C.; Xu, C.; Nair, S.; Reddy, B.; Chada, K. \& Kong, AN. (2006). Pharmacogenomics of cancer chemopreventive isothiocyanate compound sulforaphane in the intestinal polyps of ApcMin/+ mice. Biopharm Drug Dispos, 27, 407-420.

Kim, KP.; Whitehead, C.; Piazza, G. \& Wargovich, MJ. (2004). Combinatorial chemoprevention: efficacy of lovostatin and exisulind on the formation and progression of aberrant crypt foci. Anticancer Res, 24, 1805-1811.

Kulkarni, AB. \& Karlsson, S. (1993). Transforming growth factor-beta 1 knockout mice. A mutation in one cytokine gene causes a dramatic inflammatory disease. Am J Pathol, 143, 3-9.

Kullberg, MC.; Ward, JM.; Gorelick, PL.; Caspar, P.; Hieny, S.; Cheever, A.; Jankovic, D. \& Sher, A. (1998). Helicobacter hepaticus triggers colitis in specific-pathogen-free interleukin-10 (IL-10)-deficient mice through an IL-12- and gamma interferondependent mechanism. Infect Immun, 66, 5157-5166.

Kuraguchi, M.; Yang, K.; Wong, E.; Avdievich, E.; Fan, K.; Kolodner, RD.; Lipkin, M.; Brown, AM.; Kucherlapati, R. \& Edelmann, W. (2001). The distinct spectra of tumor-associated Apc mutations in mismatch repair-deficient Apc1638N mice define the roles of MSH3 and MSH6 in DNA repair and intestinal tumorigenesis. Cancer Res, 61, 7934-7942.

Kwong, LN. \& Dove, WF. (2009). APC and its modifiers in colon cancer. Adv Exp Med Biol, 656, 85-106.

Kwong, LN.; Shedlovsky, A.; Biehl, BS.; Clipson, L.; Pasch, CA. \& Dove, WF. (2007). Identification of Mom7, a novel modifier of $\mathrm{Apc}(\mathrm{Min} /+)$ on mouse chromosome 18. Genetics, 176, 1237-1244.

Le Leu, RK.; Hu, Y.; Brown, IL.; Woodman, RJ. \& Young, GP. (2010). Synbiotic intervention of Bifidobacterium lactis and resistant starch protects against colorectal cancer development in rats. Carcinogenesis, 31, 246-251. 
Lee, CC.; Gillies, ER.; Fox, ME.; Guillaudeu, SJ.; Frechet, JM.; Dy, EE. \& Szoka, FC. (2006). A single dose of doxorubicin-functionalized bow-tie dendrimer cures mice bearing C26 colon carcinomas. Proc Natl Acad Sci U S A, 103, 16649-16654.

Li, Q.; Ishikawa, TO.; Oshima, M. \& Taketo, MM. (2005). The threshold level of adenomatous polyposis coli protein for mouse intestinal tumorigenesis. Cancer Res, $65,8622-8627$.

Lieschke, GJ. \& Currie, PD. (2007). Animal models of human disease: zebrafish swim into view. Nat Rev Genet, 8, 353-367.

Luongo, C.; Moser, AR.; Gledhill, S. \& Dove, WF. (1994). Loss of Apc+ in intestinal adenomas from Min mice. Cancer Res, 54, 5947-5952.

Lynch, HT. \& de la Chapelle, A. (2003). Hereditary colorectal cancer. N Engl J Med, 348, 919932.

Lynch, HT. \& Smyrk, T. (1996). Hereditary nonpolyposis colorectal cancer (Lynch syndrome). An updated review. Cancer, 78, 1149-1167.

Mabley, JG.; Pacher, P.; Bai, P.; Wallace, R.; Goonesekera, S.; Virag, L.; Southan, GJ. \& Szabo, C. (2004). Suppression of intestinal polyposis in Apcmin/+ mice by targeting the nitric oxide or poly(ADP-ribose) pathways. Mutat Res, 548, 107-116.

Mack, DR. \& Hollingsworth, MA. (1994). Alteration in expression of MUC2 and MUC3 mRNA levels in HT29 colonic carcinoma cells. Biochem Biophys Res Commun, 199, 1012-1018.

Maggio-Price, L.; Treuting, P.; Zeng, W.; Tsang, M.; Bielefeldt-Ohmann, H. \& Iritani, BM. (2006). Helicobacter infection is required for inflammation and colon cancer in SMAD3-deficient mice. Cancer Res, 66, 828-838.

Martin, JE.; Le Leu, RK.; Hu, Y. \& Young, GP. (2010). R-flurbiprofen suppresses distal nonmucin-producing colorectal tumors in azoxymethane-treated rats, without suppressing eicosanoid production. Am J Physiol Gastrointest Liver Physiol, 298, G860-4.

McCart, AE.; Vickaryous, NK. \& Silver, A. (2008). Apc mice: models, modifiers and mutants. Pathol Res Pract, 204, 479-490.

Min, WK.; Sung, HY. \& Choi, YS. (2010). Suppression of colonic aberrant crypt foci by soy isoflavones is dose-independent in dimethylhydrazine-treated rats. J Med Food, 13, 495-502.

Miyamoto, M. \& Takizawa, S. (1975). Colon carcinoma of highly inbred rats. J Natl Cancer Inst, 55, 1471-1472.

Mizobe, T.; Ogata, Y.; Murakami, H.; Akagi, Y.; Ishibashi, N.; Mori, S.; Sasatomi, T. \& Shirouzu, K. (2008). Efficacy of the combined use of bevacizumab and irinotecan as a postoperative adjuvant chemotherapy in colon carcinoma. Oncol Rep, 20, 517-523.

Mizoguchi, E.; Mizoguchi, A.; Preffer, FI. \& Bhan, AK. (2000). Regulatory role of mature B cells in a murine model of inflammatory bowel disease. Int Immunol, 12, 597-605.

Moser, AR.; Dove, WF.; Roth, KA. \& Gordon, JI. (1992). The Min (multiple intestinal neoplasia) mutation: its effect on gut epithelial cell differentiation and interaction with a modifier system. J Cell Biol, 116, 1517-1526.

Moser, AR.; Pitot, HC. \& Dove, WF. (1990). A dominant mutation that predisposes to multiple intestinal neoplasia in the mouse. Science, 247, 322-324.

Moshal, KS.; Ferri-Lagneau, KF. \& Leung, T. (2010). Zebrafish model: worth considering in defining tumor angiogenesis. Trends Cardiovasc Med, 20, 114-119. 
Murphy, EA.; Davis, JM.; McClellan, JL.; Gordon, BT. \& Carmichael, MD. (2011). Curcumin's effect on intestinal inflammation and tumorigenesis in the ApcMin/+ mouse. $J$ Interferon Cytokine Res, 31, 219-226.

Mutanen, M.; Pajari, AM.; Paivarinta, E.; Misikangas, M.; Rajakangas, J.; Marttinen, M. \& Oikarinen, S. (2008). Berries as chemopreventive dietary constituents--a mechanistic approach with the ApcMin/+ mouse. Asia Pac J Clin Nutr, 17 Suppl 1, 123-125.

Nakanishi, Y.; Nakatsuji, M.; Seno, H.; Ishizu, S.; Akitake-Kawano, R.; Kanda, K.; Ueo, T.; Komekado, H.; Kawada, M.; Minami, M. \& Chiba, T. (2011). COX-2 inhibition alters the phenotype of tumor-associated macrophages from M2 to M1 in ApcMin/+ mouse polyps. Carcinogenesis,

Nakayama, Y.; Inoue, Y.; Minagawa, N.; Onitsuka, K.; Nagata, J.; Shibao, K.; Hirata, K.; Sako, T.; Nagata, N. \& Yamaguchi, K. (2009). Chemopreventive effect of 4-[3,5Bis(trimethylsilyl) benzamido] benzoic acid (TAC-101) on MNU-induced colon carcinogenesis in a rat model. Anticancer Res, 29, 2059-2065.

Niho, N.; Takahashi, M.; Shoji, Y.; Takeuchi, Y.; Matsubara, S.; Sugimura, T. \& Wakabayashi, K. (2003). Dose-dependent suppression of hyperlipidemia and intestinal polyp formation in Min mice by pioglitazone, a PPAR gamma ligand. Cancer Sci, 94, 960964.

Okayasu, I.; Hatakeyama, S.; Yamada, M.; Ohkusa, T.; Inagaki, Y. \& Nakaya, R. (1990). A novel method in the induction of reliable experimental acute and chronic ulcerative colitis in mice. Gastroenterology, 98, 694-702.

Oshima, M.; Murai, N.; Kargman, S.; Arguello, M.; Luk, P.; Kwong, E.; Taketo, MM. \& Evans, JF. (2001). Chemoprevention of intestinal polyposis in the Apcdelta716 mouse by rofecoxib, a specific cyclooxygenase-2 inhibitor. Cancer Res, 61, 1733-1740.

Oshima, M.; Takahashi, M.; Oshima, H.; Tsutsumi, M.; Yazawa, K.; Sugimura, T.; Nishimura, S.; Wakabayashi, K. \& Taketo, MM. (1995). Effects of docosahexaenoic acid (DHA) on intestinal polyp development in Apc delta 716 knockout mice. Carcinogenesis, 16, 2605-2607.

Papageorgis, P.; Cheng, K.; Ozturk, S.; Gong, Y.; Lambert, AW.; Abdolmaleky, HM.; Zhou, JR. \& Thiagalingam, S. (2011). Smad4 inactivation promotes malignancy and drug resistance of colon cancer. Cancer Res, 71, 998-1008.

Phutthaphadoong, S.; Yamada, Y.; Hirata, A.; Tomita, H.; Hara, A.; Limtrakul, P.; Iwasaki, T.; Kobayashi, H. \& Mori, H. (2010). Chemopreventive effect of fermented brown rice and rice bran (FBRA) on the inflammation-related colorectal carcinogenesis in ApcMin/+ mice. Oncol Rep, 23, 53-59.

Prabhu, PN.; Ashokkumar, P. \& Sudhandiran, G. (2009). Antioxidative and antiproliferative effects of astaxanthin during the initiation stages of 1,2-dimethyl hydrazineinduced experimental colon carcinogenesis. Fundam Clin Pharmacol, 23, 225-234.

Prolla, TA. (1998). DNA mismatch repair and cancer. Curr Opin Cell Biol, 10, 311-316.

Prolla, TA.; Baker, SM.; Harris, AC.; Tsao, JL.; Yao, X.; Bronner, CE.; Zheng, B.; Gordon, M.; Reneker, J.; Arnheim, N.; Shibata, D.; Bradley, A. \& Liskay, RM. (1998). Tumour susceptibility and spontaneous mutation in mice deficient in Mlh1, Pms1 and Pms2 DNA mismatch repair. Nat Genet, 18, 276-279.

Rai, K.; Sarkar, S.; Broadbent, TJ.; Voas, M.; Grossmann, KF.; Nadauld, LD.; Dehghanizadeh, S.; Hagos, FT.; Li, Y.; Toth, RK.; Chidester, S.; Bahr, TM.; Johnson, WE.; Sklow, B.; 
Burt, R.; Cairns, BR. \& Jones, DA. (2010). DNA demethylase activity maintains intestinal cells in an undifferentiated state following loss of APC. Cell, 142, 930-942.

Rajamanickam, S.; Velmurugan, B.; Kaur, M.; Singh, RP. \& Agarwal, R. (2010). Chemoprevention of intestinal tumorigenesis in APCmin/+ mice by silibinin. Cancer Res, 70, 2368-2378.

Raju, J.; Bielecki, A.; Caldwell, D.; Lok, E.; Taylor, M.; Kapal, K.; Curran, I.; Cooke, GM.; Bird, RP. \& Mehta, R. (2009). Soy isoflavones modulate azoxymethane-induced rat colon carcinogenesis exposed pre- and postnatally and inhibit growth of DLD-1 human colon adenocarcinoma cells by increasing the expression of estrogen receptor-beta. J Nutr, 139, 474-481.

Rao, CV.; Steele, VE.; Swamy, MV.; Patlolla, JM.; Guruswamy, S. \& Kopelovich, L. (2009). Inhibition of azoxymethane-induced colorectal cancer by CP-31398, a TP53 modulator, alone or in combination with low doses of celecoxib in male F344 rats. Cancer Res, 69, 8175-8182.

Raufman, JP.; Shant, J.; Xie, G.; Cheng, K.; Gao, XM.; Shiu, B.; Shah, N.; Drachenberg, C.; Heath, J.; Wess, J. \& Khurana, S. (2011). Muscarinic Receptor Subtype-3 Gene Ablation and Scopolamine ButylbromideTreatment Attenuate Small Intestinal Neoplasia in Apcmin/+ Mice. Carcinogenesis,

Reitmair, AH.; Cai, JC.; Bjerknes, M.; Redston, M.; Cheng, H.; Pind, MT.; Hay, K.; Mitri, A.; Bapat, BV.; Mak, TW. \& Gallinger, S. (1996). MSH2 deficiency contributes to accelerated APC-mediated intestinal tumorigenesis. Cancer Res, 56, 2922-2926.

Rigby, RJ.; Simmons, JG.; Greenhalgh, CJ.; Alexander, WS. \& Lund, PK. (2007). Suppressor of cytokine signaling 3 (SOCS3) limits damage-induced crypt hyper-proliferation and inflammation-associated tumorigenesis in the colon. Oncogene, 26, 4833-4841.

Ritland, SR. \& Gendler, SJ. (1999). Chemoprevention of intestinal adenomas in the ApcMin mouse by piroxicam: kinetics, strain effects and resistance to chemosuppression. Carcinogenesis, 20, 51-58.

Roy, HK.; Gulizia, JM.; Karolski, WJ.; Ratashak, A.; Sorrell, MF. \& Tuma, D. (2002). Ethanol promotes intestinal tumorigenesis in the MIN mouse. Multiple intestinal neoplasia. Cancer Epidemiol Biomarkers Prev, 11, 1499-1502.

Rudolph, U.; Finegold, MJ.; Rich, SS.; Harriman, GR.; Srinivasan, Y.; Brabet, P.; Bradley, A. \& Birnbaumer, L. (1995). Gi2 alpha protein deficiency: a model of inflammatory bowel disease. J Clin Immunol, 15, 101S-105S.

Ruivenkamp, CA.; van Wezel, T.; Zanon, C.; Stassen, AP.; Vlcek, C.; Csikos, T.; Klous, AM.; Tripodis, N.; Perrakis, A.; Boerrigter, L.; Groot, PC.; Lindeman, J.; Mooi, WJ.; Meijjer, GA.; Scholten, G.; Dauwerse, H.; Paces, V.; van Zandwijk, N.; van Ommen, GJ. \& Demant, P. (2002). Ptprj is a candidate for the mouse colon-cancer susceptibility locus Scc1 and is frequently deleted in human cancers. Nat Genet, 31, 295-300.

Rygaard, J. \& Povlsen, CO. (1969). Heterotransplantation of a human malignant tumour to "Nude" mice. Acta Pathol Microbiol Scand, 77, 758-760.

Sale, S.; Tunstall, RG.; Ruparelia, KC.; Butler, PC.; Potter, GA.; Steward, WP. \& Gescher, AJ. (2006). Effects of the potential chemopreventive agent DMU-135 on adenoma development in the ApcMin+ mouse. Invest New Drugs, 24, 459-464. 
Sasai, H.; Masaki, M. \& Wakitani, K. (2000). Suppression of polypogenesis in a new mouse strain with a truncated Apc(Delta474) by a novel COX-2 inhibitor, JTE-522. Carcinogenesis, 21, 953-958.

Seril, DN.; Liao, J.; Yang, CS. \& Yang, GY. (2005). Systemic iron supplementation replenishes iron stores without enhancing colon carcinogenesis in murine models of ulcerative colitis: comparison with iron-enriched diet. Dig Dis Sci, 50, 696-707.

Shibata, H.; Toyama, K.; Shioya, H.; Ito, M.; Hirota, M.; Hasegawa, S.; Matsumoto, H.; Takano, H.; Akiyama, T.; Toyoshima, K.; Kanamaru, R.; Kanegae, Y.; Saito, I.; Nakamura, Y.; Shiba, K. \& Noda, T. (1997). Rapid colorectal adenoma formation initiated by conditional targeting of the Apc gene. Science, 278, 120-123.

Shull, MM.; Ormsby, I.; Kier, AB.; Pawlowski, S.; Diebold, RJ.; Yin, M.; Allen, R.; Sidman, C.; Proetzel, G.; Calvin, D. \& et, a. (1992). Targeted disruption of the mouse transforming growth factor-beta 1 gene results in multifocal inflammatory disease. Nature, 359, 693-699.

Silva, MF.; Sivieri, K. \& Rossi, EA. (2009). Effects of a probiotic soy product and physical exercise on formation of pre-neoplastic lesions in rat colons in a short-term model of carcinogenic. J Int Soc Sports Nutr, 6, 17.

Smith, DL.; Keshavan, P.; Avissar, U.; Ahmed, K. \& Zucker, SD. (2010). Sodium taurocholate inhibits intestinal adenoma formation in APCMin/+ mice, potentially through activation of the farnesoid $\mathrm{X}$ receptor. Carcinogenesis, 31, 1100-1109.

Smits, BM.; Mudde, JB.; van de Belt, J.; Verheul, M.; Olivier, J.; Homberg, J.; Guryev, V.; Cools, AR.; Ellenbroek, BA.; Plasterk, RH. \& Cuppen, E. (2006). Generation of gene knockouts and mutant models in the laboratory rat by ENU-driven target-selected mutagenesis. Pharmacogenet Genomics, 16, 159-169.

Smits, R.; Kielman, MF.; Breukel, C.; Zurcher, C.; Neufeld, K.; Jagmohan-Changur, S.; Hofland, N.; van Dijk, J.; White, R.; Edelmann, W.; Kucherlapati, R.; Khan, PM. \& Fodde, R. (1999). Apc1638T: a mouse model delineating critical domains of the adenomatous polyposis coli protein involved in tumorigenesis and development. Genes Dev, 13, 1309-1321.

Sodir, NM.; Chen, X.; Park, R.; Nickel, AE.; Conti, PS.; Moats, R.; Bading, JR.; Shibata, D. \& Laird, PW. (2006). Smad3 deficiency promotes tumorigenesis in the distal colon of ApcMin/+ mice. Cancer Res, 66, 8430-8438.

Song, J.; Medline, A.; Mason, JB.; Gallinger, S. \& Kim, YI. (2000). Effects of dietary folate on intestinal tumorigenesis in the apcMin mouse. Cancer Res, 60, 5434-5440.

Sorensen, IK.; Kristiansen, E.; Mortensen, A.; Nicolaisen, GM.; Wijnands, JA.; van Kranen, HJ. \& van Kreijl, CF. (1998). The effect of soy isoflavones on the development of intestinal neoplasia in ApcMin mouse. Cancer Lett, 130, 217-225.

Steele, VE.; Rao, CV.; Zhang, Y.; Patlolla, J.; Boring, D.; Kopelovich, L.; Juliana, MM.; Grubbs, CJ. \& Lubet, RA. (2009). Chemopreventive efficacy of naproxen and nitric oxide-naproxen in rodent models of colon, urinary bladder, and mammary cancers. Cancer Prev Res (Phila), 2, 951-956.

Su, LK.; Kinzler, KW.; Vogelstein, B.; Preisinger, AC.; Moser, AR.; Luongo, C.; Gould, KA. \& Dove, WF. (1992). Multiple intestinal neoplasia caused by a mutation in the murine homolog of the APC gene. Science, 256, 668-670.

Sutherland, KD.; Vaillant, F.; Alexander, WS.; Wintermantel, TM.; Forrest, NC.; Holroyd, SL.; McManus, EJ.; Schutz, G.; Watson, CJ.; Chodosh, LA.; Lindeman, GJ. \& 
Visvader, JE. (2006). c-myc as a mediator of accelerated apoptosis and involution in mammary glands lacking Socs3. EMBO J, 25, 5805-5815.

Swamy, MV.; Patlolla, JM.; Steele, VE.; Kopelovich, L.; Reddy, BS. \& Rao, CV. (2006). Chemoprevention of familial adenomatous polyposis by low doses of atorvastatin and celecoxib given individually and in combination to APCMin mice. Cancer Res, 66, 7370-7377.

Symolon, H.; Schmelz, EM.; Dillehay, DL. \& Merrill, AHJ. (2004). Dietary soy sphingolipids suppress tumorigenesis and gene expression in 1,2-dimethylhydrazine-treated CF1 mice and ApcMin/+ mice. J Nutr, 134, 1157-1161.

Takahashi, M.; Nakatsugi, S.; Sugimura, T. \& Wakabayashi, K. (2000). Frequent mutations of the beta-catenin gene in mouse colon tumors induced by azoxymethane. Carcinogenesis, 21, 1117-1120.

Takahashi, S.; Hasegawa, R.; Masui, T.; Mizoguchi, M.; Fukushima, S. \& Ito, N. (1992). Establishment of multiorgan carcinogenesis bioassay using rats treated with a combination of five carcinogens. J. Toxicol. Pathol, 5, 151-156.

Takaku, K.; Oshima, M.; Miyoshi, H.; Matsui, M.; Seldin, MF. \& Taketo, MM. (1998). Intestinal tumorigenesis in compound mutant mice of both Dpc4 (Smad4) and Apc genes. Cell, 92, 645-656.

Tammariello, AE. \& Milner, JA. (2010). Mouse models for unraveling the importance of diet in colon cancer prevention. J Nutr Biochem, 21, 77-88.

Tanaka, T.; Kohno, H.; Suzuki, R.; Yamada, Y.; Sugie, S. \& Mori, H. (2003). A novel inflammation-related mouse colon carcinogenesis model induced by azoxymethane and dextran sodium sulfate. Cancer Sci, 94, 965-973.

Tang, B.; Bottinger, EP.; Jakowlew, SB.; Bagnall, KM.; Mariano, J.; Anver, MR.; Letterio, JJ. \& Wakefield, LM. (1998). Transforming growth factor-beta1 is a new form of tumor suppressor with true haploid insufficiency. Nat Med, 4, 802-807.

Telang, N. \& Katdare, M. (2007). Combinatorial prevention of carcinogenic risk in a model for familial colon cancer. Oncol Rep, 17, 909-914.

Tomimoto, A.; Endo, H.; Sugiyama, M.; Fujisawa, T.; Hosono, K.; Takahashi, H.; Nakajima, N.; Nagashima, Y.; Wada, K.; Nakagama, H. \& Nakajima, A. (2008). Metformin suppresses intestinal polyp growth in ApcMin/+ mice. Cancer Sci, 99, 2136-2141.

Trani, D.; Datta, K.; Doiron, K.; Kallakury, B. \& Fornace, AJJ. (2010). Enhanced intestinal tumor multiplicity and grade in vivo after HZE exposure: mouse models for space radiation risk estimates. Radiat Environ Biophys, 49, 389-396.

Tseng, W.; Leong, X. \& Engleman, E. (2007). Orthotopic mouse model of colorectal cancer. J Vis Exp, 484.

Uronis, JM.; Herfarth, HH.; Rubinas, TC.; Bissahoyo, AC.; Hanlon, K. \& Threadgill, DW. (2007). Flat colorectal cancers are genetically determined and progress to invasion without going through a polypoid stage. Cancer Res, 67, 11594-11600.

Uronis, JM. \& Threadgill, DW. (2009). Murine models of colorectal cancer. Mamm Genome, 20, 261-268.

Velmurugan, B.; Singh, RP.; Agarwal, R. \& Agarwal, C. (2010). Dietary-feeding of grape seed extract prevents azoxymethane-induced colonic aberrant crypt foci formation in fischer 344 rats. Mol Carcinog, 49, 641-652. 
Wald, D.; Qin, J.; Zhao, Z.; Qian, Y.; Naramura, M.; Tian, L.; Towne, J.; Sims, JE.; Stark, GR. $\& \mathrm{Li}$, X. (2003). SIGIRR, a negative regulator of Toll-like receptor-interleukin 1 receptor signaling. Nat Immunol, 4, 920-927.

Wang, QS.; Papanikolaou, A.; Sabourin, CL. \& Rosenberg, DW. (1998). Altered expression of cyclin D1 and cyclin-dependent kinase 4 in azoxymethane-induced mouse colon tumorigenesis. Carcinogenesis, 19, 2001-2006.

Wirtz, S. \& Neurath, MF. (2007). Mouse models of inflammatory bowel disease. Adv Drug Deliv Rev, 59, 1073-1083.

Xiao, H.; Gulen, MF.; Qin, J.; Yao, J.; Bulek, K.; Kish, D.; Altuntas, CZ.; Wald, D.; Ma, C.; Zhou, H.; Tuohy, VK.; Fairchild, RL.; de la Motte, C.; Cua, D.; Vallance, BA. \& Li, X. (2007). The Toll-interleukin-1 receptor member SIGIRR regulates colonic epithelial homeostasis, inflammation, and tumorigenesis. Immunity, 26, 461-475.

Yamaguchi, K.; Cekanova, M.; McEntee, MF.; Yoon, JH.; Fischer, SM.; Renes, IB.; Van Seuningen, I. \& Baek, SJ. (2008). Peroxisome proliferator-activated receptor ligand MCC-555 suppresses intestinal polyps in ApcMin/+ mice via extracellular signalregulated kinase and peroxisome proliferator-activated receptor-dependent pathways. Mol Cancer Ther, 7, 2779-2787.

Yang, W.; Velcich, A.; Lozonschi, I.; Liang, J.; Nicholas, C.; Zhuang, M.; Bancroft, L. \& Augenlicht, LH. (2005). Inactivation of p21WAF1/cip1 enhances intestinal tumor formation in Muc2-/- mice. Am J Pathol, 166, 1239-1246.

Yang, YA.; Dukhanina, O.; Tang, B.; Mamura, M.; Letterio, JJ.; MacGregor, J.; Patel, SC.; Khozin, S.; Liu, ZY.; Green, J.; Anver, MR.; Merlino, G. \& Wakefield, LM. (2002a). Lifetime exposure to a soluble TGF-beta antagonist protects mice against metastasis without adverse side effects. J Clin Invest, 109, 1607-1615.

Yang, YA.; Tang, B.; Robinson, G.; Hennighausen, L.; Brodie, SG.; Deng, CX. \& Wakefield, LM. (2002b). Smad3 in the mammary epithelium has a nonredundant role in the induction of apoptosis, but not in the regulation of proliferation or differentiation by transforming growth factor-beta. Cell Growth Differ, 13, 123-130.

Zan, Y.; Haag, JD.; Chen, KS.; Shepel, LA.; Wigington, D.; Wang, YR.; Hu, R.; LopezGuajardo, CC.; Brose, HL.; Porter, KI.; Leonard, RA.; Hitt, AA.; Schommer, SL.; Elegbede, AF. \& Gould, MN. (2003). Production of knockout rats using ENU mutagenesis and a yeast-based screening assay. Nat Biotechnol, 21, 645-651.

Zhu, Y.; Richardson, JA.; Parada, LF. \& Graff, JM. (1998). Smad3 mutant mice develop metastatic colorectal cancer. Cell, 94, 703-714. 


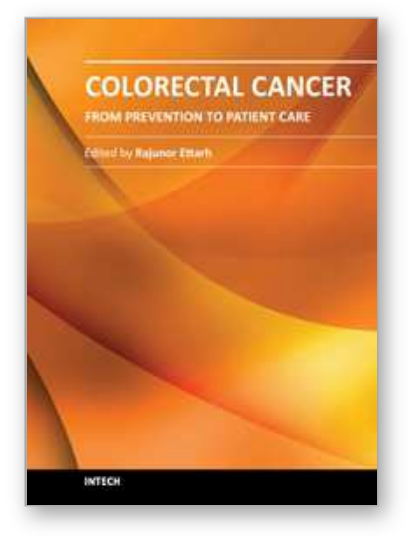

\author{
Colorectal Cancer - From Prevention to Patient Care \\ Edited by Dr. Rajunor Ettarh
}

ISBN 978-953-51-0028-7

Hard cover, 538 pages

Publisher InTech

Published online 17, February, 2012

Published in print edition February, 2012

The projections for future growth in the number of new patients with colorectal cancer in most parts of the world remain unfavorable. When we consider the substantial morbidity and mortality that accompanies the disease, the acute need for improvements and better solutions in patient care becomes evident. This volume, organized in five sections, represents a synopsis of the significant efforts from scientists, clinicians and investigators towards finding improvements in different patient care aspects including nutrition, diagnostic approaches, treatment strategies with the addition of some novel therapeutic approaches, and prevention. For scientists involved in investigations that explore fundamental cellular events in colorectal cancer, this volume provides a framework for translational integration of cell biological and clinical information. Clinicians as well as other healthcare professionals involved in patient management for colorectal cancer will find this volume useful.

\title{
How to reference
}

In order to correctly reference this scholarly work, feel free to copy and paste the following:

Shubhankar Suman, Albert J. Fornace Jr. and Kamal Datta (2012). Animal Models of Colorectal Cancer in Chemoprevention and Therapeutics Development, Colorectal Cancer - From Prevention to Patient Care, Dr. Rajunor Ettarh (Ed.), ISBN: 978-953-51-0028-7, InTech, Available from:

http://www.intechopen.com/books/colorectal-cancer-from-prevention-to-patient-care/animal-models-ofcolorectal-cancer-in-chemoprevention-and-therapeutics-development

\section{INTECH}

open science | open minds

\section{InTech Europe}

University Campus STeP Ri

Slavka Krautzeka 83/A

51000 Rijeka, Croatia

Phone: +385 (51) 770447

Fax: +385 (51) 686166

www.intechopen.com

\section{InTech China}

Unit 405, Office Block, Hotel Equatorial Shanghai

No.65, Yan An Road (West), Shanghai, 200040, China

中国上海市延安西路65号上海国际贵都大饭店办公楼 405 单元

Phone: +86-21-62489820

Fax: $+86-21-62489821$ 
(C) 2012 The Author(s). Licensee IntechOpen. This is an open access article distributed under the terms of the Creative Commons Attribution 3.0 License, which permits unrestricted use, distribution, and reproduction in any medium, provided the original work is properly cited. 